\title{
Defoliation Timing Effects on Spotted Knapweed Seed Production and Viability
}

\author{
Katie R. Benzel, ${ }^{1}$ Tracy K. Mosley, ${ }^{2}$ and Jeffrey C. Mosley ${ }^{3}$ \\ Authors are ${ }^{1}$ Wildlife Biologist, Bureau of Land Management, Dillon, MT 59725, USA; ${ }^{2}$ Agriculture Extension Agent, Montana State University \\ Extension, Livingston, MT 59047, USA; and ${ }^{3}$ Professor, Department of Animal and Range Sciences, Montana State University, Bozeman,
} MT 59717, USA.

\begin{abstract}
Spotted knapweed (Centaurea stoebe L.), a perennial invasive forb that reproduces largely by seed, often forms new flowers after prescribed sheep grazing or mowing is applied during the bolting or flowering stage. It is unknown if these new flowers produce viable seeds by the end of the growing season. The purpose of this 2-yr study was to determine the appropriate timing (or timings) or combination (or combinations) of timings of defoliation on spotted knapweed to reduce its viable seed production. Spotted knapweed plants on foothill rangeland in west-central Montana were hand-clipped at seven different timings and frequencies of defoliation: June (bolting stage); July (late-bud-early flowering stage); August (full-flowering stage); June + July; June + August; July + August; or June + July + August. Unclipped plants were controls. Plants clipped in the bolting stage were defoliated at $35-40 \%$ relative utilization. Plants clipped at all other timings had $100 \%$ of their buds and flowers removed, plus $3 \mathrm{~cm}$ of each bud or flower stem. Plant response was evaluated from mid-August through September, whenever the seed heads of each treatment's plants reached maturity but while their seed-head bracts remained tightly closed. Clipping at any timing or combination of timings reduced the number of buds and flower heads per plant $(P<0.01)$, number of seeds per plant $(P<0.01)$, percentage of viability of seeds $(P<0.01)$, and number of viable seeds per plant $(P<0.01)$ compared with no clipping. Clipping during the bolting stage reduced the number of viable seeds by nearly $90 \%$ compared with no clipping. Clipping during the late-bud-early-flower or full-flower stage reduced the number of viable seeds by nearly $100 \%$ compared with no clipping. Spotted knapweed defoliation via prescribed sheep grazing or mowing in summer should suppress viable seed production of spotted knapweed.
\end{abstract}

\section{Resumen}

Spotted knapweed (Centaurea stoebe L.), es una herbácea invasiva perenne que se reproduce principalmente por medio de semilla, algunas veces produce nuevas estructuras florales después de pastoreo prescrito con ovejas o de cortes aplicados durante la época previa a la floración o durante la etapa de floración. Se desconoce si estas nuevas estructuras florales producen semillas viables durante la etapa final de la época de crecimiento. El objetivo de estos dos años de estudio fue determinar el calendario(os) apropiado o la combinación (es) de calendarios de defoliación sobre Spotted Knapweed para reducir la producción de semillas viables. Plantas de Spotted knapweed en pastizales con lomeríos en la parte central-oeste de Montana USA, se cortaron a mano en 7 diferentes épocas y frecuencias de defoliación: en Junio (etapa previa a la floración); Julio (finales de la brotación/ principios de la época de floración); Agosto (etapa de floración completa); Junio + Julio; Junio + Agosto; Julio + Agosto; o Junio + Julio + agosto. Las plantas que no fueron cortadas se utilizaron como control. Las plantas cortadas en la época previa a la floración fueron defoliadas en un $35-40 \%$ de su relativa utilización. Las plantas cortadas en todas las otras épocas, el 100\% de sus yemas/flores fueron removidas, más $3 \mathrm{~cm}$ yemas/tallos florales. La respuesta de las plantas se evaluó desde mediados de Agosto hasta Septiembre, siempre y cuando la parte floral de las semillas de cada planta tratada hubieran alcanzado la maduración pero la parte floral de semillas permaneciera bien cerrada. Los cortes en cualquier calendario o combinación de calendarios redujo el número de yemas/cabezas florales por planta $(P<0.01)$, la cantidad de semillas por planta $(P<0.01)$, porcentaje de viabilidad de las semillas $(P<0.01)$, y el numero de semillas viables por planta $(P<0.01)$, comparado con los testigos. Los cortes durante la etapa previa a la floración redujo el número de semillas viables cerca del $90 \%$ comparado con los testigos. Los cortes durante la etapa de finalización de producción de yema/producción floral o durante el estado d floración completa redujo el número de semillas viables cerca del 100\% comparado con los testigos. La defoliación sobre Spotted knapweed a través del pastoreo de ovejas o cortes en verano podría suprimir la producción de semillas viables de Spotted Knapweed.

Key Words: Centaurea maculosa, Centaurea stoebe, clipping, prescribed sheep grazing, targeted grazing, weeds

\section{INTRODUCTION}

Research was funded by Western Sustainable Agriculture Research and Education and the Joe Skeen Institute for Rangeland Restoration.

At the time of research, Benzel was a graduate research assistant, Dept of Animal and Range Sciences, Montana State University, Bozeman, MT, USA.

Correspondence: Dr Tracy Mosley, Park County Extension, 414 E Callender, Livingston, MT 59047, USA. Email: tmosley@montana.edu

Manuscript received 24 September 2008; manuscript accepted 23 August 2009.
Spotted knapweed (Centaurea stoebe L.) is a deeply taprooted, invasive perennial forb infesting millions of hectares of native rangeland in the United States and Canada (Watson and Renney 1974; Jacobs and Sheley 1998). Spotted knapweed was first recorded in the Pacific Northwest in the late 1800s (Watson and Renney 1974). It is currently documented to infest 
every US state except Alaska, Texas, Oklahoma, and Mississippi (US Department of Agriculture, Natural Resources Conservation Service [USDA, NRCS] 2008) and causes severe economic impacts. In Montana alone, more than US\$42 million is lost annually to Montana's economy in direct and indirect costs associated with spotted knapweed (Hirsch and Leitch 1996). Unlike most other invasive species, spotted knapweed does not require disturbance to invade an area. It can readily establish itself on pristine rangelands (Tyser and Key 1988). Spotted knapweed is capable of forming large monocultures, lowers plant diversity (Tyser and Key 1988), decreases the abundance and diversity of native soil microbes (Broz et al. 2007), reduces livestock and wildlife forage (Watson and Renney 1974; Harris and Cranston 1979; Thompson 1996), and increases surface water runoff and sediment yield (Lacey et al. 1989).

Spotted knapweed is a prolific seed producer, producing $5000-40000$ seeds $\cdot \mathrm{m}^{-2}$ each year (Sheley et al. 1998), with current years' seeds averaging $60-82 \%$ viability (Jacobs and Sheley 1998). Seeds can remain viable in the soil for at least $8 \mathrm{yr}$ (Davis et al. 1993). Herbicides are commonly used for spotted knapweed control; however, chemical control is hampered by reinfestation from seed reserves in the soil (Nolan and Upadhyaya 1988). High seed output and seed longevity in the soil make long-term control of spotted knapweed difficult and expensive (Schirman 1981; Griffith and Lacey 1991; Davis et al. 1993). One key to suppressing a noxious weed is preventing its reproduction (DiTomaso 2000).

Prescribed sheep grazing is a useful method of spotted knapweed control (Olson et al. 1997), especially when mechanical, cultural, biological, and chemical methods are restricted or constrained by environmental or economic concerns (Olson and Lacey 1994). Sheep grazing is well suited for spotted knapweed control because sheep usually prefer forbs over grasses (Hanley 1982), sheep are adapted to grazing steep topography (Olson and Lacey 1994), and sheep have a cleft upper lip and narrow muzzle, allowing greater selectivity of plant parts (Arnold and Dudzinski 1978). For example, relative utilization of spotted knapweed by sheep averaged $35 \%$ to $50 \%$ in June or July, whereas relative utilization of desirable graminoid forage averaged only $15 \%$ except under exceptionally hot and dry conditions (Thrift et al. 2008). Sheep grazing of this noxious weed may decrease its competitiveness with native grasses (Olson and Wallander 2001).

Sheep readily ingest spotted knapweed buds and flower heads throughout summer (Olson and Wallander 2001), and removal of spotted knapweed buds, flower heads and seed heads by sheep grazing can reduce spotted knapweed seed production. For example, three summers of sheep grazing in southwestern Montana reduced the number of viable spotted knapweed seeds in the seed bank by $54 \%$, whereas the number of viable spotted knapweed seeds in the soil of the ungrazed control site increased $88 \%$ during the same 3-yr period (Olson et al. 1997). Mowing during the flowering stage or bud and flowering stage reduced spotted knapweed seed germination from $91 \%$ to $19 \%$, and mowing during the bud stage, flowering stage, or the bud-and-flowering stage reduced the number of seed-producing spotted knapweed plants by $91 \%$ (Watson and Renney 1974).

However, spotted knapweed produces new, additional flowers before the end of the growing season after being defoliated during the bolting or flowering stages (Watson and Renney 1974). Research has yet to determine if these new flowers produce viable seed. Because spotted knapweed is a prolific seed producer, optimizing the timing (or timings) of defoliation to reduce its viable seed production and consequent input into the seed bank would improve the efficacy of prescribed sheep grazing or mowing for spotted knapweed control. The objective of our research was to determine the appropriate timing (or timings) or combination (or combinations) of timings of spotted knapweed defoliation to reduce its viable seed production.

\section{MATERIALS AND METHODS}

\section{Study Area}

This 2-yr study was located $5 \mathrm{~km}$ east of Helmville, Montana (lat $46^{\circ} 98^{\prime} \mathrm{N}$, long $\left.113^{\circ} 05^{\prime} \mathrm{W}\right)$. The ecological site is Silty, in the 380-480-mm precipitation zone (USDA, NRCS 2007). Elevation at the site is about $1400 \mathrm{~m}$, and the site is classified as a rough fescue (Festuca campestris Rydb.)/bluebunch wheatgrass (Pseudoroegneria spicata [Pursh] A. Love) habitat type (Mueggler and Stewart 1980). The 30-yr average annual precipitation is $318 \mathrm{~mm}$, with $56 \%$ occurring as rain between May and September (Western Regional Climate Center [WRCC] 2008). The 30-yr average minimum and maximum temperatures are $3.8^{\circ} \mathrm{C}$ and $21.8^{\circ} \mathrm{C}$ in June, $5.3^{\circ} \mathrm{C}$ and $26.6^{\circ} \mathrm{C}$ in July, $4.1^{\circ} \mathrm{C}$ and $26.7^{\circ} \mathrm{C}$ in August, and $-0.3^{\circ} \mathrm{C}$ and $20.7^{\circ} \mathrm{C}$ in September, respectively. In addition to spotted knapweed, which is the dominant forb, common forbs included lupine (Lupinus spp.), western yarrow (Achillea millefolium L.), yellow salsify (Tragopogon dubius Scop.), common dandelion (Taraxacum officinale G. H. Weber ex Wiggers), and wild onion (Allium spp.). Idaho fescue (Festuca idaboensis Elmer), green needlegrass (Nassella viridula [Trin.] Barkworth), Sandberg bluegrass (Poa secunda J. Presl), and bluebunch wheatgrass are the predominant grass species. Mountain big sagebrush (Artemisia tridentata Nutt. subsp. vaseyana [Rydb.] Beetle) is the dominant shrub on the site.

\section{Treatments}

Eighty single-stem spotted knapweed plants between $23 \mathrm{~cm}$ and $36 \mathrm{~cm}$ in height were selected each year $(2006$ and 2007) on a site moderately infested with spotted knapweed $(36 \%$ of vegetative composition; Thrift et al. 2008). The areas containing the 80 plants $\left(286 \mathrm{~m}^{2}\right)$ were fenced with $1.8-\mathrm{m}$-tall welded wire panels to exclude ungulate grazing. The 2007 exclosure was located about $75 \mathrm{~m}$ from the 2006 exclosure to ensure that results from the two years were independent. Individual plants were located a minimum of $1 \mathrm{~m}$ apart, and identification tags were placed at the base of each stem. Before the initial clipping treatment in June each year, to account for potential competition surrounding each treatment plant, percentage of canopy cover of spotted knapweed, lupine, and perennial graminoids were estimated inside a 1 -m-diameter $\left(0.79-\mathrm{m}^{2}\right)$ circular plot surrounding each plant, and the initial height of each treatment plant was measured to the nearest centimeter. Eight hand-clipped treatments emulating observed sheep grazing behavior were applied to the individual spotted 
knapweed plants, with 10 plants included in each of the eight treatments $\left(n=80\right.$ plants $\left.\cdot \mathrm{yr}^{-1}\right)$.

Spotted knapweed plants were clipped either in mid-June (bolting stage); mid-July (late-bud-early flowering stage); midAugust (full-flowering stage); mid-June + mid-July; mid-June + mid-August; mid-July + mid-August; or mid-June + mid-July + mid-August. Unclipped plants were controls. Plants clipped in the bolting stage were defoliated at $35-40 \%$ relative utilization. Plants clipped at all other timings had $100 \%$ of their buds and flowers removed, plus $3 \mathrm{~cm}$ of stem below each bud or flower. The $35-40 \%$ relative utilization level during the bolting stage was determined by a previous study at the same study site, in which the relative utilization of spotted knapweed by sheep grazing on a landscape scale was $35-40 \%$ during the bolting stage (Thrift et al. 2008). The $3 \mathrm{~cm}$ of foliage clipped beneath the buds or flowers was based on personal observations of how sheep graze spotted knapweed buds and flowers. Clipping treatments in July or August alone resulted in less relative utilization of spotted knapweed than in the June treatment. Overall, clipping in June, July, or August resulted in light defoliation intensity ( $\leq 40 \%$ relative utilization) on spotted knapweed plants.

\section{Response Variables}

Response variables in this study included the following: 1) number of buds and flowers per plant; 2) number of doughy, intermediate, and mature seeds per plant; 3 ) total number of seeds per plant; 4) percentage of viability of doughy, intermediate, and mature seeds; 5) number of viable doughy, intermediate, and mature seeds per plant; and 6) total number of viable seeds per plant. Spotted knapweed plant response was evaluated whenever each treatment's plants reached senescence (mid-August through September), when seeds were developed to their fullest possible extent but while seed-head bracts remained closed, and before seed dispersal (Watson and Renney 1974; Schirman 1981).

Number of Buds and Flower Heads. For each treatment, the number of buds and flower heads per plant was counted prior to being collected. Immature buds, distinguished from newly forming leaves by visible bracts, were included in the final count. The number of buds and flower heads with evidence of gall fly (Urophora quadrifasciata [Meigen]) damage was recorded during bud and flower head collection.

Number of Seeds. The number of doughy, intermediate, and mature seeds per plant and total number of seeds per plant were counted in the laboratory. Seeds were extracted from seed heads using a rub board. Seeds from each plant were then divided into three developmental stages: 1 ) doughy (tiny, flat, seed coat nearly translucent), 2) intermediate (medium-sized, somewhat filled, seed coat light brown), and 3) mature (large, full and rounded, seed coat hard and black) and were counted by stage. Total number of seeds per plant was calculated by adding the number of seeds in each of the three developmental stages. When seeds were extracted from seed heads in the laboratory, the number of seed heads with evidence of gall fly damage was recorded.

Percentage of Viability of Seeds. Seeds were tested for viability using the tetrazolium test (Peters 2004). Three subsamples from each of the doughy, intermediate, and mature developmental stages of each treatment plant were used. Seeds within a given developmental stage were randomly assigned to one of three subsamples. Each subsample contained either 20 seeds or one-third of the total number of seeds in that developmental stage, whichever was greater. Percentage of viability was calculated by averaging the proportion of viable seeds in each of the three subsamples.

Number of Viable Seeds. The number of viable doughy, intermediate, and mature seeds per plant and the total number of viable seeds per plant were determined using values from the number of seeds per plant and the percentage of viability of seeds. The number of viable doughy, intermediate, and mature seeds was calculated by multiplying the number of seeds in each developmental stage by the percentage of viability of seeds in each respective developmental stage. Total number of viable seeds per plant was calculated by summing the number of viable seeds in the three developmental stages.

\section{Statistical Analysis}

Experimental design for this study was completely randomized. Treatments were arranged in an $8 \times 2$ factorial arrangement, with eight timings or combinations of timings of defoliation and two years. The statistical model included year, timing of defoliation, and year $\times$ timing interaction. Individual plants were the experimental units.

Data were analyzed using the GLM procedure of SAS (SAS Institute 2004). Percentage data and nonpercentage data that were not normally distributed were arcsine- and square roottransformed, respectively, to stabilize variances and better approximate normal distribution of residuals (Steel and Torrie 1980; Kuehl 2000). Means and standard errors presented in the text and tables are from untransformed data. Analysis of covariance was used to compare responses among treatments. Percentage of canopy cover of spotted knapweed, lupine, and perennial graminoids; percentage of buds and flowers with evidence of gall fly damage; and initial plant height were used as covariables in the analyses. Fisher's Protected LSD Test was used to compare treatment means (Steel and Torrie 1980), and differences were considered significant at $P \leq 0.05$.

\section{RESULTS}

Spotted knapweed produced new buds and flowers after plants were clipped once, twice, or three times during summer. However, all seven clipping treatments reduced the number of buds and flower heads present at the end of the growing season compared with no clipping $(P<0.01)$. Clipped plants produced $73-98 \%$ fewer buds and flower heads than unclipped plants (Table 1).

All seven clipping treatments also reduced seed production by spotted knapweed. The number of doughy seeds, intermediate seeds, mature seeds, and total seeds were all reduced by clipping $(P<0.01)$. Clipping in June during the bolting stage reduced the total number of seeds $75-81 \%$, whereas clipping at all other times or combinations of timings reduced the total number of seeds produced $98-100 \%$ (Table 2).

No doughy seeds were viable throughout the study. Clipping in June during the bolting stage reduced percentage of viability 
Table 1. Number of buds and flower heads ( \pm SE) produced per spotted knapweed plant after defoliation at different timings and combinations of timings on foothill rangeland in western Montana.

\begin{tabular}{|c|c|c|c|}
\hline \multirow[b]{2}{*}{ Treatment } & \multicolumn{2}{|c|}{ Year } & \multirow[b]{2}{*}{ Mean } \\
\hline & 2006 & 2007 & \\
\hline & \multicolumn{3}{|c|}{ - } \\
\hline Control & $23.8(3.4) a^{1}$ & $19.1(3.4) \mathrm{a}$ & $21.3(2.4) \mathrm{a}$ \\
\hline June $^{2}$ & $7.8(1.5) b$ & $4.0(0.7) b$ & $5.9(0.9) b$ \\
\hline July $^{3}$ & $8.2(2.1) b$ & $2.7(1.0) b c$ & $5.5(1.3) b$ \\
\hline August $^{4}$ & $2.6(0.6) \mathrm{c}$ & $1.9(0.6) \mathrm{cd}$ & $2.3(0.4) \mathrm{c}$ \\
\hline June + July & $4.2(2.2) \mathrm{c}$ & $2.2(1.2) \mathrm{ce}$ & $3.3(1.3) \mathrm{c}$ \\
\hline June + August & $0.3(0.2) d$ & $0.3(0.2)$ de & $0.3(0.1) d$ \\
\hline July + August & $1.9(0.9) \mathrm{cd}$ & $1.4(0.6) \mathrm{cd}$ & $1.7(0.5)$ ce \\
\hline June + July + August & $0.3(0.2) d$ & $0.4(0.2)$ de & $0.4(0.1)$ de \\
\hline
\end{tabular}

of intermediate seeds $57 \%(P<0.01)$, whereas clipping at all other timings or combinations of timings reduced percentage of viability of intermediate seeds $99 \%$ compared with no clipping $(P<0.01$; Table 3$)$. All seven clipping treatments also reduced the percentage of viability of mature seeds. Clipping in June during the bolting stage reduced percentage of viability of mature seeds $23-58 \%$, whereas clipping at all other timings or combinations of timings reduced percentage of viability of mature seeds $58-99.6 \%$ (Table 3).

The numbers of viable intermediate, mature, and total seeds were all reduced by clipping $(P<0.01)$. Clipping in June during the bolting stage reduced the total number of viable seeds nearly $90 \%$ compared with no clipping (Table 4). Clipping in July during the late-bud-early-flower stage, clipping in August during the full-flower stage, or clipping at any combination of timings reduced the total number of viable seeds almost $100 \%$ compared with no clipping (Table 4).

\section{DISCUSSION}

All defoliation treatments in our study reduced the number of viable seeds produced by spotted knapweed. This finding helps explain why a previous study in southwestern Montana reported that more viable spotted knapweed seeds were recovered from seed bank soil cores from ungrazed areas than from areas that were grazed by sheep in mid-June, July, and early September (Olson et al. 1997). Our results indicate that viable seed production of spotted knapweed is most effectively suppressed by defoliation during either the late-bud-earlyflower stage or the full-flower stage.

Our findings of the appropriate time for defoliation align favorably with results from studies of sheep foraging behavior when sheep prescriptively graze within spotted knapweed infestations. Sheep readily consume the buds and flower heads of spotted knapweed, including during late summer (Olson and Wallander 2001). In western Montana, sheep prescriptively grazed on a landscape scale in July or August commonly consume $>90 \%$ of spotted knapweed buds and flower heads (J. Mosley, unpublished data, 2007). Sheep in moderate to heavy spotted knapweed infestations typically consume less graminoids and more spotted knapweed when prescribed sheep grazing occurs in the late-bud-early-flower stage rather than the bolting stage (Thrift et al. 2008). The late-bud-early-flower stage and the full-flower stage of spotted knapweed usually occur after rangeland graminoids have set seed and become less palatable and less vulnerable to defoliation (Olson et al. 1997; Thrift et al. 2008), but while the forage volume and nutritive value of spotted knapweed remain high (Olson and Wallander 2001; Thrift et al. 2008). It should be noted that $22 \%$ of mature spotted knapweed seeds remain viable after passing through the digestive system of a sheep (Wallander et al. 1995). However, mature spotted knapweed seeds are not formed until postflowering in mid-August (Watson and Renney 1974); therefore, if grazing sheep ingest spotted knapweed buds and flower heads before the full-flower stage, sheep will not ingest nor excrete viable seeds, nor collect viable seeds in their wool.

Spotted knapweed plants that were hand-clipped in our study responded similarly to spotted knapweed plants in other studies that were defoliated by prescribed sheep grazing. For example, clipping in our study during the bolting stage or late-bud-earlyflower stage reduced the number of buds and flower heads $73 \%$, whereas clipping during the full-flower stage reduced the number of buds and flower heads $89 \%$ compared with unclipped plants. Similarly, Cox (1989) observed that when prescribed sheep grazing was applied in western Montana during the rosette stage (June 1) or the late-bolting-early-bud stage (July 1), there was a $68 \%$ and $80 \%$ reduction, respectively, in the number of plants that flowered. Fewer seed heads were also present at the end of the growing season in southeastern Idaho when prescribed sheep grazing was applied during the flowering stage than during the bolting or rosette stages (Launchbaugh and Hendrickson 2001).

Clipping effects in our study compare favorably with previous studies of mowing treatments within spotted knapweed infestations. Mowing during the full-flower stage reduced spotted knapweed seed germination $71 \%$ in western Canada (Watson and Renney 1974). In southwestern Montana, Rinella et al. (2001) reported that $3 \mathrm{yr}$ of mowing during the late-floweringseed-set stage (late August) reduced spotted knapweed canopy cover $83-85 \%$ and reduced the density of adult spotted knapweed plants $65-88 \%$. Furthermore, mowing once each year during the late-flowering-seed-set stage suppressed spotted knapweed as much as mowing two, three, or 10 times per summer. The late-flowering-seed set stage recommended for mowing by Rinella et al. (2001) is a slightly more advanced phenological stage than the late-bud-early-flower stage or the full-flower stage that we found optimal for suppressing viable seed production of spotted knapweed. Rinella et al. (2001) did not evaluate mowing only once during either the late-bud-earlyflower stage or the full-flower stage, but we suspect that mowing during these phenological stages would suppress spotted knapweed as much or more than mowing during the lateflowering-seed-set stage. Spotted knapweed plants in the latebud-early flower stage or the full-flower stage have greater numbers of actively growing meristems than plants in more advanced phenological stages. Following defoliation, the active meristems act as sinks and draw more photosynthate (Briske and Richards 1995). Plants defoliated late in the growing season may have insufficient time before dormancy to replenish the 
Table 2. Number of doughy, intermediate, and mature spotted knapweed seeds ( $\pm \mathrm{SE}$ ) per plant produced after defoliation at different timings and combinations of timings on foothill rangeland in western Montana.

\begin{tabular}{|c|c|c|c|c|}
\hline \multirow[b]{2}{*}{ Seed stage } & \multirow[b]{2}{*}{ Treatment } & \multicolumn{2}{|c|}{ Year } & \multirow[b]{2}{*}{ Mean } \\
\hline & & 2006 & 2007 & \\
\hline & & 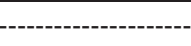 & $-\left(\right.$ No. $\cdot$ plant $\left.^{-1}\right)$ & 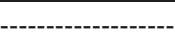 \\
\hline \multirow[t]{8}{*}{ Doughy } & Control & $144.9(30.4) \mathrm{a}^{1}$ & $155.5(28.2) \mathrm{a}$ & $150.5(20.1) \mathrm{a}$ \\
\hline & June $^{2}$ & $61.1(16.9) \mathrm{b}$ & $34.2(9.6) \mathrm{b}$ & $47.7(9.9) \mathrm{b}$ \\
\hline & July $^{3}$ & $13.5(7.9) \mathrm{C}$ & $6.6(2.9) \mathrm{c}$ & $10.1(4.2) \mathrm{C}$ \\
\hline & August $^{4}$ & $0 \mathrm{c}$ & $0 \mathrm{c}$ & $0 \mathrm{~d}$ \\
\hline & June + July & $16.0(13.8) \mathrm{c}$ & $1.6(1.6) \mathrm{c}$ & $9.2(7.3) \mathrm{cd}$ \\
\hline & June + August & $0 \mathrm{c}$ & $0 \mathrm{c}$ & $0 \mathrm{~d}$ \\
\hline & July + August & $0.3(0.3) \mathrm{c}$ & $1.2(1.2) \mathrm{C}$ & $0.8(0.6) d$ \\
\hline & June + July + August & $0 \mathrm{C}$ & $0 \mathrm{c}$ & $0 \mathrm{~d}$ \\
\hline \multirow[t]{8}{*}{ Intermediate } & Control & $20.4(3.5) \mathrm{a}$ & $29.0(6.9) \mathrm{a}$ & $24.9(4.0) \mathrm{a}$ \\
\hline & June & $6.9(2.5) \mathrm{b}$ & $2.0(0.5) \mathrm{b}$ & $4.5(1.4) b$ \\
\hline & July & $3.3(2.4) \mathrm{bc}$ & $1.3(0.9) b c$ & $2.3(1.3) \mathrm{c}$ \\
\hline & August & $0 \mathrm{c}$ & $0 \mathrm{c}$ & $0 \mathrm{~d}$ \\
\hline & June + July & $1.3(1.3) \mathrm{c}$ & $0 \mathrm{c}$ & $0.7(0.7) \mathrm{cd}$ \\
\hline & June + August & $0 \mathrm{c}$ & $0 \mathrm{c}$ & $0 \mathrm{~cd}$ \\
\hline & July + August & $0 \mathrm{C}$ & $0 \mathrm{c}$ & $0 \mathrm{~d}$ \\
\hline & June + July + August & $0 \mathrm{c}$ & $0 \mathrm{c}$ & $0 \mathrm{~d}$ \\
\hline \multirow[t]{8}{*}{ Mature } & Control & $196.9(35.1) \mathrm{a}$ & $24.7(6.3) \mathrm{a}$ & $106.3(26.1)^{5}$ \\
\hline & June & $22.6(7.1) b$ & $4.5(2.6) \mathrm{b}$ & $13.6(4.2)$ \\
\hline & July & $0.5(0.5) \mathrm{c}$ & $1.9(0.9) b c$ & $1.2(0.5)$ \\
\hline & August & $\mathrm{OC}$ & $0 \mathrm{C}$ & 0 \\
\hline & June + July & $0.1(0.1) \mathrm{c}$ & $0 \mathrm{c}$ & $0.1(0.1)$ \\
\hline & June + August & $0 \mathrm{c}$ & $0 \mathrm{c}$ & 0 \\
\hline & July + August & $0 \mathrm{C}$ & $0 \mathrm{c}$ & 0 \\
\hline & June + July + August & $0 \mathrm{c}$ & $0 \mathrm{c}$ & 0 \\
\hline \multirow[t]{8}{*}{ Total } & Control & $362.2(61.8) \mathrm{a}$ & $209.2(37.5) \mathrm{a}$ & $281.7(38.7)^{5}$ \\
\hline & June & $90.6(22.5) \mathrm{b}$ & 40.7 (11.5) b & $65.7(13.6)$ \\
\hline & July & $17.3(9.8) \mathrm{C}$ & $9.8(4.4) \mathrm{C}$ & $13.6(5.3)$ \\
\hline & August & $0 \mathrm{C}$ & 0 de & 0 \\
\hline & June + July & $17.4(15.2) \mathrm{C}$ & $1.6(1.6) \mathrm{cd}$ & $9.9(8.1)$ \\
\hline & June + August & $0 \mathrm{c}$ & 0 de & 0 \\
\hline & July + August & $0.3(0.3) \mathrm{c}$ & $1.2(1.2) \mathrm{ce}$ & $0.8(0.6)$ \\
\hline & June + July + August & $0 \mathrm{C}$ & 0 de & 0 \\
\hline
\end{tabular}

${ }^{1}$ Means in the same column within seed stage followed by the same letter are not different $(P>0.05)$.

${ }^{2}$ Spotted knapweed in bolting stage.

${ }^{3}$ Spotted knapweed in late-bud-early-flower stage.

${ }^{4}$ Spotted knapweed in full-flower stage.

${ }^{5}$ Treatment-by-year interaction $(P \leq 0.05)$.

photosynthate that was allocated to the active meristems immediately following defoliation, resulting in weakened plants entering dormancy with fewer carbon reserves (Dahl 1986).

Intermediate seeds and mature seeds from unclipped spotted knapweed plants in our study averaged $35 \%$ and $89 \%$ viability, respectively, whereas the weighted average of intermediate and mature seed viability from unclipped plants was $69 \%$. This result compares favorably with previous reports of $60-82 \%$ viability of current years' seeds (Jacobs and Sheley 1998).

Our clipping treatments reduced spotted knapweed seed production more in 2007 than 2006. It is well established that spotted knapweed produces fewer seeds in drier years (Schir- man 1981; Sheley et al. 1998), and it appears that our clipping treatments more effectively reduced spotted knapweed seed production when combined with less crop-year precipitation in 2007. In the Intermountain Region, the crop year begins 1 July and ends 30 June of the following year (Sneva and Hyder 1962; Sneva and Britton 1983). However, precipitation in July and August is typically very low and does not promote plant growth, therefore a crop year beginning 1 September and ending 30 June may be more appropriate for assessing the influence of precipitation on rangeland plant productivity in this region (Sneva and Hyder 1962; Sneva and Britton 1983). On our study site, precipitation in the 2007 crop year 
Table 3. Viability (\%) of intermediate and mature spotted knapweed seeds ( \pm SE) per plant produced after defoliation at different timings and combinations of timings on foothill rangeland in western Montana.

\begin{tabular}{|c|c|c|c|c|}
\hline \multirow[b]{2}{*}{ Seed stage } & \multirow[b]{2}{*}{ Treatment } & \multicolumn{2}{|c|}{ Year } & \multirow[b]{2}{*}{ Mean } \\
\hline & & 2006 & 2007 & \\
\hline & & ----------------. & - $(\%)$ & 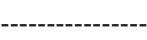 \\
\hline \multirow[t]{8}{*}{ Intermediate } & Control & $25.0(7.4) a^{1}$ & $44.8(7.4) \mathrm{a}$ & $35.4(5.6) \mathrm{a}$ \\
\hline & June $^{2}$ & $13.5(6.7) b$ & $16.7(10.2) b$ & $15.1(5.9) b$ \\
\hline & July $^{3}$ & $\mathrm{OC}$ & $6.0(6.0) b c$ & $3.0(3.0) \mathrm{C}$ \\
\hline & August ${ }^{4}$ & $0 \mathrm{c}$ & $\mathrm{OC}$ & $\mathrm{OC}$ \\
\hline & June + July & $0 \mathrm{c}$ & $0 \mathrm{c}$ & $0 \mathrm{c}$ \\
\hline & June + August & $0 \mathrm{c}$ & $0 \mathrm{c}$ & $0 \mathrm{C}$ \\
\hline & July + August & $0 \mathrm{c}$ & $0 \mathrm{c}$ & $0 \mathrm{c}$ \\
\hline & June + July + August & $0 \mathrm{c}$ & $0 \mathrm{c}$ & $0 \mathrm{C}$ \\
\hline \multirow[t]{8}{*}{ Mature } & Control & $89.0(2.0) \mathrm{a}$ & $89.0(2.4) \mathrm{a}$ & $89.0(1.5)^{5}$ \\
\hline & June & $68.2(12.0) \mathrm{b}$ & $35.1(14.6) b$ & $51.7(10.0)$ \\
\hline & July & $2.0(2.0) \mathrm{C}$ & $40.0(16.3) b$ & $21.0(9.1)$ \\
\hline & August & $0 \mathrm{c}$ & $0 \mathrm{C}$ & 0 \\
\hline & June + July & $0 \mathrm{c}$ & $0 \mathrm{c}$ & 0 \\
\hline & June + August & $0 \mathrm{c}$ & $0 \mathrm{C}$ & 0 \\
\hline & July + August & $0 \mathrm{c}$ & $0 \mathrm{C}$ & 0 \\
\hline & June + July + August & $0 \mathrm{C}$ & $0 \mathrm{C}$ & 0 \\
\hline
\end{tabular}

${ }^{1}$ Means in the same column within seed stage followed by the same letter are not different $(P>0.05)$.

${ }^{2}$ Spotted knapweed in bolting stage.

${ }^{3}$ Spotted knapweed in late-bud-early-flower stage.

${ }^{4}$ Spotted knapweed in full-flower stage.

${ }^{5}$ Treatment-by-year interaction $(P \leq 0.05)$.

(beginning 1 September 2006 and ending 30 June 2007) was $25 \mathrm{~mm}$ less than precipitation in the 2006 crop year (beginning 1 September 2005 and ending 30 June 2006; WRCC 2008).

It is noteworthy that although crop-year precipitation was less in 2007 than 2006, precipitation in both crop years exceeded the 30 -yr average $(22 \%$ and $13 \%$ above average in 2006 and 2007, respectively; WRCC 2008). We suspect that defoliation of spotted knapweed in summer would likely reduce spotted knapweed seed production even further during drier years than did clipping during the relatively wet years of our study.

\section{MANAGEMENT IMPLICATIONS}

Spotted knapweed reproduces largely by seed; therefore, prescribed sheep grazing or mowing should effectively suppress its reproduction when spotted knapweed is defoliated during the bolting, late-bud-early-flower, or full-flower stages. New flowers that are produced after defoliation earlier in the same summer produce very few to no viable seeds. Defoliation during the bolting stage can reduce the number of viable seeds nearly $90 \%$, but the most effective time of defoliation is during the late-bud-early-flower stage or the full-flower stage, which reduces viable seed production nearly $100 \%$.

If spotted knapweed is prescriptively grazed or mowed during the bolting stage, an additional defoliation during the late-budearly-flower or full-flower stage is recommended for the best control. However, if spotted knapweed plants are prescriptively
Table 4. Number of viable intermediate and mature spotted knapweed seeds ( \pm SE) produced per plant after defoliation at different timings and combinations of timings on foothill rangeland in western Montana.

\begin{tabular}{|c|c|c|c|c|}
\hline \multirow[b]{2}{*}{ Seed stage } & \multirow[b]{2}{*}{ Treatment } & \multicolumn{2}{|c|}{ Year } & \multirow[b]{2}{*}{ Mean } \\
\hline & & 2006 & 2007 & \\
\hline & & \multicolumn{3}{|c|}{ (No. · plant ${ }^{-1}$ ) - } \\
\hline \multirow[t]{8}{*}{ Intermediate } & Control & $6.1(2.0) \mathrm{a}^{1}$ & $10.4(2.4) \mathrm{a}$ & $8.4(1.6)^{2}$ \\
\hline & June $^{3}$ & $1.4(0.6) b$ & $0.3(0.2) \mathrm{b}$ & $0.9(0.3)$ \\
\hline & July ${ }^{4}$ & $0 \mathrm{c}$ & $0.3(0.3) \mathrm{b}$ & $0.2(0.2)$ \\
\hline & August $^{5}$ & $0 \mathrm{c}$ & $\mathrm{Ob}$ & 0 \\
\hline & June + July & $0 \mathrm{c}$ & $0 \mathrm{~b}$ & 0 \\
\hline & June + August & $0 \mathrm{c}$ & $0 \mathrm{~b}$ & 0 \\
\hline & July + August & $0 \mathrm{c}$ & $0 \mathrm{~b}$ & 0 \\
\hline & June + July + August & $0 \mathrm{c}$ & $0 \mathrm{~b}$ & 0 \\
\hline
\end{tabular}

\begin{tabular}{|c|c|c|c|c|}
\hline \multirow[t]{8}{*}{ Mature } & Control & \multicolumn{2}{|c|}{$173.0(30.3)$ a $21.0(4.9)$ a } & $93.0(22.8)^{2}$ \\
\hline & June & $20.1(6.7) b$ & $3.5(1.9) b$ & $11.8(3.9)$ \\
\hline & July & $0.1(0.1) \mathrm{C}$ & $1.9(0.9) b c$ & $1.0(0.5)$ \\
\hline & August & $0 \mathrm{c}$ & $0 \mathrm{c}$ & 0 \\
\hline & June + July & $0 \mathrm{c}$ & $0 \mathrm{c}$ & 0 \\
\hline & June + August & $0 \mathrm{c}$ & $0 \mathrm{c}$ & 0 \\
\hline & July + August & $0 \mathrm{c}$ & $0 \mathrm{c}$ & 0 \\
\hline & June + July + August & $0 \mathrm{c}$ & $0 \mathrm{c}$ & 0 \\
\hline \multirow[t]{8}{*}{ Total } & Control & \multicolumn{2}{|c|}{$179.1(29.8)$ a $31.4(5.7)$ a } & $101.4(22.3)^{2}$ \\
\hline & June & $21.5(7.3) \mathrm{b}$ & $3.8(1.8) \mathrm{b}$ & $12.7(4.2)$ \\
\hline & July & $0.1(0.1) \mathrm{c}$ & $2.2(1.2) b c$ & $1.2(0.6)$ \\
\hline & August & $0 \mathrm{c}$ & $0 \mathrm{c}$ & 0 \\
\hline & June + July & $0 \mathrm{c}$ & $0 \mathrm{c}$ & 0 \\
\hline & June + August & $0 \mathrm{c}$ & $0 \mathrm{c}$ & 0 \\
\hline & July + August & $0 \mathrm{c}$ & $0 \mathrm{c}$ & 0 \\
\hline & June + July + August & $0 \mathrm{c}$ & $0 \mathrm{c}$ & 0 \\
\hline
\end{tabular}

${ }^{1}$ Means in the same column within seed stage followed by the same letter are not different $(P>0.05)$.

${ }^{2}$ Treatment-by-year interaction $(P \leq 0.05)$.

${ }^{3}$ Spotted knapweed in bolting stage.

${ }^{4}$ Spotted knapweed in late-bud-early-flower stage.

${ }^{5}$ Spotted knapweed in full-flower stage.

grazed or mowed during the late-bud-early-flower or full-flower stage, an additional defoliation is not necessary.

Sheep do not need to be quarantined before moving to a new area if they graze spotted knapweed during the bolting or latebud-early-flower stages, because spotted knapweed plants at these phenological stages do not contain viable seed. Viable seeds also are not present when a seed head is in the full-flower stage; however, when an infestation is characterized on whole to be in the full-flower stage, viable seeds are probably present on some individual spotted knapweed plants that are more pheonologically advanced. Therefore, mowing only once per summer during the full-flower stage is not recommended because viable seeds will likely be contributed to the soil seed bank, and sheep that prescriptively graze only once per summer during the full-flower stage should be quarantined in a corral for $7 \mathrm{~d}$ to allow viable seeds to be excreted before moving the sheep to a new area (Wallander et al. 1995). If, however, prescribed sheep grazing or mowing is applied twice per summer (e.g., June + July, June + August, or July + August), the new flowers produced after the first 
grazing or mowing treatment do not contain viable seeds; therefore, the risk of spreading viable seed is much lower after sheep regraze an infestation later in summer, and remowing an infestation later in summer will contribute few, if any, viable seeds to the soil seed bank.

\section{ACKNOWLEDGMENTS}

Authors wish to thank Dave Mannix and Mannix Brothers Ranch for use of their land for this project. Thanks to John Terry and Lucy Cooke for assistance with seed viability testing; Ashley Beyer, Josh Bilbao, Greg Iverson, Stacee Henderson, and Dr Rachel Frost for help with data collection; and Dr Bret Olson for helpful comments on earlier drafts of this manuscript.

\section{LITERATURE CITED}

Arnold, G. W., And M. L. Dudzinski. 1978. Ethology of free ranging domestic animals. New York, NY, USA: Elsevier Scientific Publishing. 198 p.

BrISKE, D. D., AND J. H. RichaRds. 1995. Plant responses to defoliation: a physiological, morphological and demographic evaluation. In: D. J. Bedunah and R. E. Sosebee [EDS.]. Wildland plants: physiological ecology and developmental morphology. Denver, CO, USA: Society for Range Management. p. $635-710$.

Broz, A. K., D. K. Manter, and J. M. Vivanco. 2007. Soil fungal abundance and diversity: another victim of the invasive plant Centaurea maculosa. International Society for Microbial Ecology Journal 1:763-765.

Cox, J. W. 1989. Observations, experiments and suggestions for research on the sheep-spotted knapweed relationship. In: P. K. Fay and J. R. Lacey [EDS.]. Proceedings of the Knapweed Symposium; 4-5 April 1989; Bozeman, MT, USA. Bozeman, MT, USA: Montana State University, Plant and Soil Science Department. p. 79-82.

DAHL, B. E. 1986. Using range resources for best ranching success. In: D. E. Guynn and T. R. Troxel [EDs.]. Proceedings of the 1986 International Ranchers Roundup; 18-21 August 1986; Kerrville, TX, USA. College Station, TX, USA: Texas A\&M University. p. 147-156.

Davis, E. S., P. K. Fay, T. K. Chicoine, and C. A. Lacey. 1993. Persistence of spotted knapweed (Centaurea maculosa) seed in soil. Weed Science 41:57-61.

DiTomaso, J. M. 2000. Invasive weeds in rangelands: species, impacts, and management. Weed Science 48:255-265.

Griffith, D., And J. R. LACEY. 1991. Economic evaluation of spotted knapweed (Centaurea maculosa) control using picloram. Journal of Range Management 44:43-47.

Hanley, T. A. 1982. The nutritional basis for food selection by ungulates. Journal of Range Management 35:146-151.

Harris, P., and R. Cranston. 1979. An economic evaluation of control methods for diffuse and spotted knapweed in western Canada. Canadian Journal of Plant Science 59:375-382.

HiRsch, S. A., AND J. A. Leitch. 1996. The impact of knapweed on Montana's economy. Fargo, ND, USA: North Dakota State University Agricultural Experiment Station, Agricultural Economics Report 355. 43 p.

JaCOBS, J. S., AND R. L. Sheley. 1998. Observation: life history of spotted knapweed. Journal of Range Management 51:665-673.

KuEHL, R. 0. 2000. Design of experiments: statistical principles of research design and analysis. 2nd ed. Pacific Grove, CA, USA: Duxberry Press. 666 p.

Lacey, J. R., C. B. Marlow, and J. R. Lane. 1989. Influence of spotted knapweed (Centaurea maculosa) on surface runoff and sediment yield. Weed Technology 3:627-631.
Launchbaugh, K., and J. Hendrickson. 2001. Prescription grazing for Centaurea control on rangelands. In: L. Smith [ED.]. The First International Knapweed Symposium of the Twenty-First Century; 15-16 March 2001; Coeur d' Alene, ID, USA. Albany, CA, USA: US Department of Agriculture, Agricultural Research Service. p. 27-32.

Muegglen, W. F., And W. L. Stewart. 1980. Grassland and shrubland habitat types of western Montana. Ogden, UT, USA: US Department of Agriculture, Forest Service, Intermountain Forest and Range Experiment Station, General Technical Report INT-66. $154 \mathrm{p}$.

Nolan, D. G., and M. K. Upadhyaya. 1988. Primary seed dormancy in diffuse and spotted knapweed. Canadian Journal of Plant Science 68:775-783.

OLSON, B. E., AND J. R. LACEY. 1994. Sheep: a method for controlling rangeland weeds. Sheep Research Journal 10:105-112.

Olson, B. E., and R. T. Wallander. 2001. Sheep grazing spotted knapweed and Idaho fescue. Journal of Range Management 54:25-30.

Olson, B. E., R. T. Wallander, And J. R. Lacey. 1997. Effects of sheep grazing on a spotted knapweed-infested Idaho fescue community. Journal of Range Management 50:386-390.

Peters, J. [ed.]. 2004. Asteraceae. Tetrazolium testing handbook for agricultural seeds, contribution no. 29 of the handbook on seed testing. Lincoln, NE, USA: Association of Official Seed Analysts. 2 p.

Rinella, M. J., J. S. Jacobs, R. L. Sheley, and J. J. Borkowski. 2001. Spotted knapweed response to season and frequency of mowing. Journal of Range Management 54:52-56.

SAS InStITUte. 2004. SAS/STAT 9.1 user's guide. Cary, NC, USA: SAS Institute, Inc. $5136 \mathrm{p}$.

ScHIRMAn, R. 1981. Seed production and spring seedling establishment of diffuse and spotted knapweed. Journal of Range Management 34:45-47.

Sheley, R. L., J. S. Jacobs, and M. F. Carpinelli. 1998. Distribution, biology, and management of diffuse (Centaurea diffusa) and spotted knapweed (Centaurea maculosa). Weed Technology 12:353-362.

Sneva, F., and C. M. Britton. 1983. Adjusting and forecasting herbage yields in the Intermountain big sagebrush region of the steppe province. Corvallis, $\mathrm{OR}$, USA: Oregon State University Agricultural Experiment Station Bulletin 659. $61 \mathrm{p}$.

Sneva, F. A., and D. N. Hyder. 1962. Estimating herbage production on semiarid ranges in the Intermountain Region. Journal of Range Management 15:88-93.

Steel, R. G. D., and J. H. TorRie. 1980. Principles and procedures of statistics: a biometrical approach. 2nd ed. New York, NY, USA: McGrawHill. $633 \mathrm{p}$.

Thompson, M. J. 1996. Winter foraging response of elk to spotted knapweed removal. Northwest Science 70:10-19.

Thrift, B. D., J. C. Mosley, T. K. Brewer, B. L. Roeder, B. E. Olson, and R. W. Kott. 2008. Prescribed sheep grazing to suppress spotted knapweed on foothill rangeland. Rangeland Ecology \& Management 61:18-25.

TYSER, R. W., AND C. H. KeY. 1988. Spotted knapweed in natural area fescue grasslands: an ecological assessment. Northwest Science 62:151-160.

[USDA, nRCS] US Department of Agriculture, Natural Resources Conservation Service. 2007. Web soil survey of Powell County area, MT. Available at: http:// websoilsurvey.nrcs.usda.gov/app/. Accessed 6 November 2007.

[USDA, NRCS] US Department of Agriculture, Natural Resources Conservation SeRvice. 2008. The PLANTS database. Available at: http://plants.usda.gov. Accessed 23 May 2008.

Wallander, R. T., B. E. Olson, and J. R. Lacey. 1995. Spotted knapweed seed viability after passing through sheep and mule deer. Journal of Range Management 48:145-149.

Watson, A. K., and A. J. Renney. 1974. The biology of Canadian weeds. Centaurea diffusa and C. maculosa. Canadian Journal of Plant Science 54:687-701.

[WRCC] Western Regional Climate Center. 2008. Period of record monthly climate summary, Ovando 9 SSE, Montana (246304). Available at: http://www.wrcc. dri.edu. Accessed 23 May 2008. 